\title{
INTERNALISASI NILAI KARAKTER NASIONALIS DALAM PEMBELAJARAN IPS UNTUK MEMBANGUN JATI DIRI KE-INDONESIA-AN
}

\section{INTERNALIZATION OF NATIONAL CHARACTER VALUE IN SOCIAL STUDIES TO BUILD THE IDENTITY OF INDONESIA}

\author{
Utomo, Eko Prasetyo \\ SMP Negeri Model Terpadu Bojonegoro \\ tom.ekop10@gmail.com
}

\begin{abstract}
Abstrak
Gejala memudarnya jati diri ke-Indonesia-an dikalangan generasi muda utamanya para pelajar pada tingkat yang mengkhawatirkan seperti tidak mampu menghafal sila Pancasila, lagu Indonesia Raya, dan Bhinneka Tunggal Ika, hingga tidak mengerti batas-batas wilayah Indonesia. Fokus penelitian ini adalah menggali proses dan makna internalisasi nilai karakter nasionalis dalam pembelajaran IPS. Penelitian ini menggunakan pendekatan kualitatif dengan desain penelitian fenomenologi. Subjek penelitian adalah siswa SMP Negeri Model Terpadu Bojonegoro dengan menggunakan teknik purposive sampling. Pengumpulan data dilakukan dengan teknik wawancara, observasi, dan kuesioner. Hasil penelitian ini menunjukkan bahwa nilai karakter nasionalis diinternalisasikan dalam tiga tahap yaitu 1) transformasi nilai; 2) transaksi nilai; dan 3) transisternalisasi nilai. Proses internalisasi nilai karakter nasionalis dalam pembelajaran IPS melalui mediator keteladanan guru dan kegiatan praktik langsung pengalaman belajar seperti model pembelajaran, metode pembelajaran, bahan ajar, dan evaluasi pembelajaran. Perilaku berkarakter nasionalis yang diaktualisasikan dalam kehidupan sehari-hari di sekolah oleh siswa yaitu disiplin, cinta tanah air, semangat kebangsaan, cinta damai, peduli lingkungan, menghargai prestasi, dan toleransi.
\end{abstract}

Kata kunci: Internalisasi, Nasionalis, IPS, Jati diri ke-Indonesia-an

\begin{abstract}
The phenomenon of waning of Indonesian identity among the younger generation is mainly the students at an alarming level such as not being able to memorize the precepts of Pancasila, Indonesia Raya song, and Bhinneka Tunggal Ika, to not understand the boundaries of Indonesian territory. The focus of this research is to explore the process and meaning of internalization of nationalist character values in IPS learning. This research uses qualitative approach with phenomenology research design. The subjects of the study were students of SMP Negeri Model Integrated Bojonegoro by using purposive sampling technique. Data were collected by interview, observation, and questionnaire. The results of this study indicate that the value of nationalist character is internalized in three stages: 1) value transformation; 2) value transactions; And 3) value transisternalization. The process of internalizing the value of nationalist character in IPS learning through teacher modeling exemplars and direct practice of learning experiences such as learning model, learning method, teaching materials, and learning evaluation. The nationalistic characteristic behavior that is actualized in daily life at school by the students is discipline, love of the homeland, the spirit of nationalism, the love of peace, the care of the environment, the appreciation of achievement, and the tolerance.
\end{abstract}

Keywords: Internalization, National, Social Studies, Indonesia's identity 


\section{Pendahuluan}

Akhir-akhir ini masyarakat sering dibuat resah dengan berbagai kasus yang dipertontonkan oleh kalangan pelajar yang menyimpang dari norma baik agama, moral, kesusilaan, dan hukum seperti tindak kekerasan (bullying), pemakaian narkoba, melakukan hubungan sex dan tindak aborsi pada remaja. Pernyataan ini dibuktikan dengan beberapa berita baik melalui media cetak maupun elektronik. Salah satu kasus yang akhir-akhir ini diberitakan yaitu tentang kekerasan (bullying) dan tawuran. Bentukbentuk perilaku tersebut diatas menunjukkan bahwa telah terjadi krisis jati diri dikalangan generasi muda khususnya para pelajar.

Lickona (2013, p.13) berpendapat bahwa terdapat sepuluh karakteristik jaman yang harus diwaspadai karena jika karakteristik tersebut ada di kalangan remaja berarti sebuah bangsa sedang menuju jurang kehancuran. Kesepuluh karakteristik tersebut adalah 1) meningkatnya kekerasan dan pengrusakan (Viollencen and vandalisme); 2) meningkatnya pencurian yang dilakukan siswa (Stealing); 3) maraknya penjiplakan/ketidakjujuran (Cheating); 4) semakin rendahnya rasa hormat kepada orang tua atau yang dituakan (disrespect of outhority); 5) pengaruh peer group yang kuat dalam tindakan kekerasan (peer cruelty); 6) berprasangka buruk, intoleransi, dan memusuhi orang-orang dari keyakinan yang berbeda (Bigotry); 7) penggunaan bahasa dan kata-kata yang semakin memburuk (bad language); 8) kebebasan sexualitas dan adanya rasa saling curiga dan kebencian di antara sesama (sexual precocity and abuse); 9) semakin rendahnya tanggung jawab individu dan warga negara (Increasing selfcenteredness and declining civic resposibility); dan 10) meningkatnya perilaku merusak diri, seperti: penggunaan narkoba, alkohol, dan lain-lain (self-destructive behavior).
Nampaknya apa yang terjadi di Indonesia akhir-akhir ini di kalangan para pelajar bila dibandingkan dengan kualitas moral yang perlu diwaspadai seperti yang telah dikemukakan oleh Lickona diatas diperlukan perhatian tersendiri. Beberapa kasus lain juga menunjukkan bahwa generasi muda saat ini juga krisis jati diri ke-Indonesia-an atau nasionalisme. Nasionalisme itu sendiri artikan sebagai ideologi yang mencakup prinsip kebebasan, kesatuan, kesamarataan, serta kepribadian selaku orientasi nilai kehidupan kolektif suatu kelompok dalam usahanya merealisasikan tujuan politik yakni pembentukan dan pelestarian negara nasional (Kartodirdjo, 1994, p.4). Gejala lunturnya jati diri ke-Indonesia-an tersebut tercermin dalam sikap dan perilaku mereka seperti tidak mampu menghafal sila Pancasila, lagu Indonesia Raya, dan Bhinneka Tunggal Ika, hingga tidak mengerti batas-batas wilayah Indonesia.

Lebih lanjut semangat nasionalisme dalam negara kebangsaan dijiwai oleh lima prinsip nasionalisme, yakni: 1) kesatuan (unity), dalam wilayah teritorial, bangsa, bahasa, ideologi, dan doktrin kenegaraan, sistem politik atau pemerintahan, sistem perekonomian, sistem pertahanan keamanan, dan policy kebudayan; 2) kebebasan (liberty, freedom, independence), dalam beragama, berbicara dan berpendapat lisan dan tertulis, berkelompok dan berorganisasi; 3) kesamaan (equality), dalam kedudukan hukum, hak dan kewajiban; 4) kepribadian (personality) dan identitas (identity), yaitu memiliki harga diri (self estreem), rasa bangga (pride) dan rasa sayang (depotion) terhadap kepribadian dan identitas bangsanya yang tumbuh dari dan sesuai dengan sejarah dan kebudayaannya; 5) prestasi (achievement), yaitu cita-cita untuk mewujudkan kesejahteraan (welfare) serta kebesaran dan kemanusiaan (the greatnees adn the glorification) dari bangsanya (Kartodirdjo, 1999, p.7). 
Sejalan dengan fenomena dekadensi moral dan lunturnya jati diri ke-Indonesia-an, Presiden Joko Widodo memberikan penekanan khusus dalam Nawacita butir 8 yaitu melakukan revolusi karakter bangsa melalui kebijakan penataan kembali kurikulum pendidikan nasional dengan mengedepankan aspek pendidikan kewarganegaraan, yang menempatkan secara proporsional aspek pendidikan, seperti pengajaran sejarah pembentukan bangsa, nilai-nilai patriotisme dan cinta Tanah Air, semangat bela negara dan budi pekerti di dalam kurikulum pendidikan Indonesia (Anonim, 2014, p.10). Sehingga nampak jelas disini bahwa prioritas pemerintah saat ini membangun jati diri ke-Indonesi-an yang di era globalisasi sekarang ini mulai luntur.

Gerakan Penguatan Pendidikan Karakter (PPK) itu sendiri merupakan kelanjutan dan kesinambungan dari Gerakan Nasional Pendidikan Karakter Bangsa Tahun 2010. Tujuan program PPK adalah menanamkan nilai-nilai pembentukan karakter bangsa secara masif dan efektif melalui implementasi nilai-nilai utama Gerakan Nasional Revolusi Mental (religius, nasionalis, mandiri, gotongroyong dan integritas) yang akan menjadi fokus pembelajaran, pembiasaan, dan pembudayaan, sehingga pendidikan karakter bangsa sungguh dapat mengubah perilaku, cara berpikir dan cara bertindak seluruh bangsa Indonesia menjadi lebih baik dan berintegritas (Kemdikbud, 2017, p.1).

Berbeda dengan pendidikan budaya dan karakter bangsa yang mempunyai delapan belas nilai sebagai fokus utama, dalam PPK hanya ada lima nilai utama karakter yang saling berkaitan membentuk jejaring nilai yang perlu dikembangkan sebagai prioritas Gerakan PPK. Kelima nilai utama karakter bangsa yang dimaksud yaitu: 1) religious; 2) nasionalis; 3) mandiri; 4) gotong royong; dan $5)$ integritas.

Dalam upaya membangun jati diri keIndonesia-an maka perlu diperkuat kembali nilai karakter nasionalis. Nilai karakter nasionalis merupakan cara berpikir, bersikap, dan berbuat yang menunjukkan kesetiaan, kepedulian, dan penghargaan yang tinggi terhadap bahasa, lingkungan fisik, sosial, budaya, ekonomi, dan politik bangsa, menempatkan kepentingan bangsa dan negara di atas kepentingan diri dan kelompoknya. Subnilai nasionalis antara lain apresiasi budaya bangsa sendiri, menjaga kekayaan budaya bangsa,rela berkorban, unggul, dan berprestasi, cinta tanah air, menjaga lingkungan,taat hukum, disiplin, menghormati keragaman budaya, suku,dan agama (Kemdikbud, 2016, p.8). Prinsip implementasinya, PPK dilaksanakan dengan berbasis kelas, berbasis budaya sekolah, dan berbasis budaya masyarakat.

Nilai karakter nasionalis berbasis kelas terintegrasi ke dalam mata pelajaran dalam hal ini penting untuk di integrasikan pada mata pelajaran IPS. Dalam Permendiknas No.26 tahun 2007 tentang Standar isi, Mata pelajaran IPS pada jenjang SMP/ MTs mengkaji seperangkat peristiwa, fakta, konsep, dan generalisasi yang berkaitan dengan isu sosial sehingga siswa diharapkan dapat menjadi warga negara Indonesia yang demokratis dan bertanggung jawab serta warga dunia yang cinta damai.

Lebih lanjut mata pelajaran IPS pada jenjang SMP/MTs mempunyai karakteristik tersendiri yaitu merupakan perpaduan disiplin ilmu sosial yaitu Sosiologi, Geografi, Sejarah, dan Ekonomi yang diberikan secara terpadu terkait satu sama lain sehingga output yang diharapkan yaitu siswa menjadi warga negara yang berketerampilan dan berkepedulian sosial serta bertanggung jawab sesuai dengan nilai-nilai yang terkandung dalamnya.

Guru mengintegrasikan nilai karakter nasionalis kedalam Silabus dan Rencana Program Pembelajaran (RPP) IPS dapat memberikan pengalaman yang bermakna karena pserta didik dapat memahami, menginternalisasi, dan mengaktualisasikannya 
melalui poses pembelajaran sehingga nilainilai tersebut dapat terserap secara alami lewat kegiatan sehari-hari di kelas. Berkenaan peran peserta didik sebagai warga negara Indonesia yang demokratis dan bertanggung jawab serta warga dunia yang cinta damai seperti yang diuraikan diatas disadari betul penguatan karakter menjadi prioritas utama saat ini karena sudah terbukti bahwa dalam kehidupan masyarakat sangat banyak masalah yang ditimbulkan oleh karakter yang kurang baik.

Atas dasar pemikiran di atas, untuk membentuk karakter nasionalis yang baik dalam mata pelajaran IPS dalam rangka membangun jati diri ke-Indonesia-an, maka seharusnya dalam PPK tidak sekedar mengenalkan nilai karakter nasionalis tersebut kepada siswa tetapi juga harus mampu menginternalisasikan nilai-nilai karakter tersebut agar tertanam sebagai muatan hati nurani yang mampu membangkitkan penghayatan tentang nilai-nilai, dan bahkan sampai pada pengamalanya dalam kehidupan sehari-hari.

Proses internalisasi yang dikaitkan dengan pembinaan peserta didik atau anak asuh ada tiga tahap yang mewakili proses atau tahap terjadinya internalisasi yaitu: a) Tahap transformasi nilai, tahap ini merupakan suatu proses yang dilakukan oleh pendidik dalam menginformasikan nilai-nilai yang baik dan kurang baik. Komunikasi yang terjadi dalam tahap ini adalah komunikasi verbal antara pendidik dan peserta didik atau anak asuh; b) Tahap transaksi nilai, adalah suatu tahap pendidikan nilai dengan jalan melakukan komunikasi dua arah atau komunikasi antar peserta didik dengan pendidik yang bersifat interaksi timbal balik; dan c) Tahap transisternalisasi, tahap ini jauh lebih mendalam dari tahap transaksi. Tahap ini tidak hanya dilakukan dengan komunikasi verbal tetapi juga dengan sikap mental dan kepribadian. Jadi pada tahap ini, komunikasi kepribadian berperan secara aktif (Muhaimin, 2001, p.153).
Internalisasi nilai karakter nasionalis dalam pembelajaran IPS pada siswa SMP sangat menarik untuk diteliti. Fenomena dekadensi moral dan gejala lunturnya jati diri ke-Indoneis-an yang ditunjukkan oleh pelajar akhir-akhir ini menunjukkan bahwa mereka belum mampu menginternalisasi nilai karakter nasionalis agar tertanam dan berfungsi sebagai muatan hati nurani sehingga mampu membengkitkan penghayatan tentang nilai karakter tersebut karakter. Tentu hal ini tidak sesuai dengan tujuan pembelajaran IPS.

Berdasarkan uraian tersebut di atas, maka fokus penelitian ini: 1) bagaimanakah internalisasi nilai karakter nasionalis dalam pembelajaran IPS untuk membangun jati diri ke-Indonesia-an dan 2) apakah makna internalisasi nilai karakter nasionalis dalam pembelajaran IPS untuk membangun jati diri ke-Indonesia-an menurut pandangan siswa di SMP Negeri Model Terpadu Bojonegoro.

Adapun tujuan dari penelitian ini: 1) mengidentifikasi internalisasi nilai karakter nasionalis dalam pembelajaran IPS untuk membangun jati diri ke-Indonesia-an dan 2) mengidentifikasi makna internalisasi nilai karakter nasionalis dalam pembelajaran IPS untuk membangun jati diri ke-Indonesia-an menurut pandangan siswa di SMP Negeri Model Terpadu Bojonegoro.

\section{Metode Penelitian}

Desain Penelitian

Penelitian ini menggunakan pendekatan kualitatif dengan desain penelitian fenomenologi. Penelitian ini dilakukan untuk mengidentifikasi proses internalisasi nilai karakter nasionalis dalam pembelajaran IPS pada diri siswa dan mengidentifikasi makna internalisasi nilai karakter nasionalis menurut pandangan siswa.

\section{Informan Penelitian}

Informan dalam penelitian ini dipilih secara purposive, cara memilih sejumlah responden yang disesuaikan dengan tujuan penelitian. Informan dalam penelitian ini adalah siswa kelas IX sejumlah delapan anak, mereka dipilih berdasarkan hasil pra observasi 
pada pembelajaran IPS yang telah dilakukan. Siswa yang menjadi informan adalah mereka yang mempunyai pengetahuan yang baik tentang pendidikan karakter yaitu mereka mampu mendiskripsikan apa yang mereka rasakan, apa yang mereka pikirkan, dan apa yang mereka lakukan tentang proses internalisasi nilai karakter nasionalis dalam pembelajaran IPS pada diri mereka.

Tempat dan Waktu Penelitian

Tempat penelitian ini ada di SMP Negeri Model Terpadu Bojonegoro. Pemilihan sekolah ini sebagai tempat penelitian sesuai dengan pengamatan pra observasi dari peneliti yaitu sekolah ini sudah melaksanakan pendidikan karakter secara komprehenship dan telah mempunyai Standar budaya dan karakter bangsa pada Komponen Standar Nasional Pendidikan selain delapan standar nasional pendidikaan yang lainnya. Waktu penelitian dilakukan bulan Februari-April 2017.

Instrumen Penelitian.

Instrument yang digunakan dalam penelitian ini berupa manusia, yaitu peneliti sendiri.

Prosedur Pengumpulan Data
Ketepatan pemilihan prosedur pengumpulan data menentukan kesesuaian data yang diharapkan. Dalam penelitian yang akan dilakukan, peneliti menggunakan teknik pengumpulan data wawancara, studi dokumentasi, dan observasi.

\section{Validasi data}

Untuk menjaga keabsahan data, digunakan teknik perpanjangan waktu penelitian, triangulasi, dan expert opinion.

\section{Teknik Analisis Data.}

Teknik analisis data mengacu pada langkah-langkah analisis data kualitatif Creswell (2013, p.277) sebagai berikut: (1) mengolah dan mempersiapkan data untuk dianalisis, (2) membaca keseluruhan data dengan membangun general sense atas informasi yang diperoleh dan merefleksikan maknanya secara keseluruhan, menganalisis lebih detail dengan meng-coding data, (4) melakukan proses coding untuk mendiskripsikan setting, orang-orang, kategori-kategori, dan tema-tema yang akan di analisis, (5) menyusun diskripsi dari tematema dan disajikan kembali dalam narasi/laporan kualitatif, dan mengintepretasi atau memaknai data.

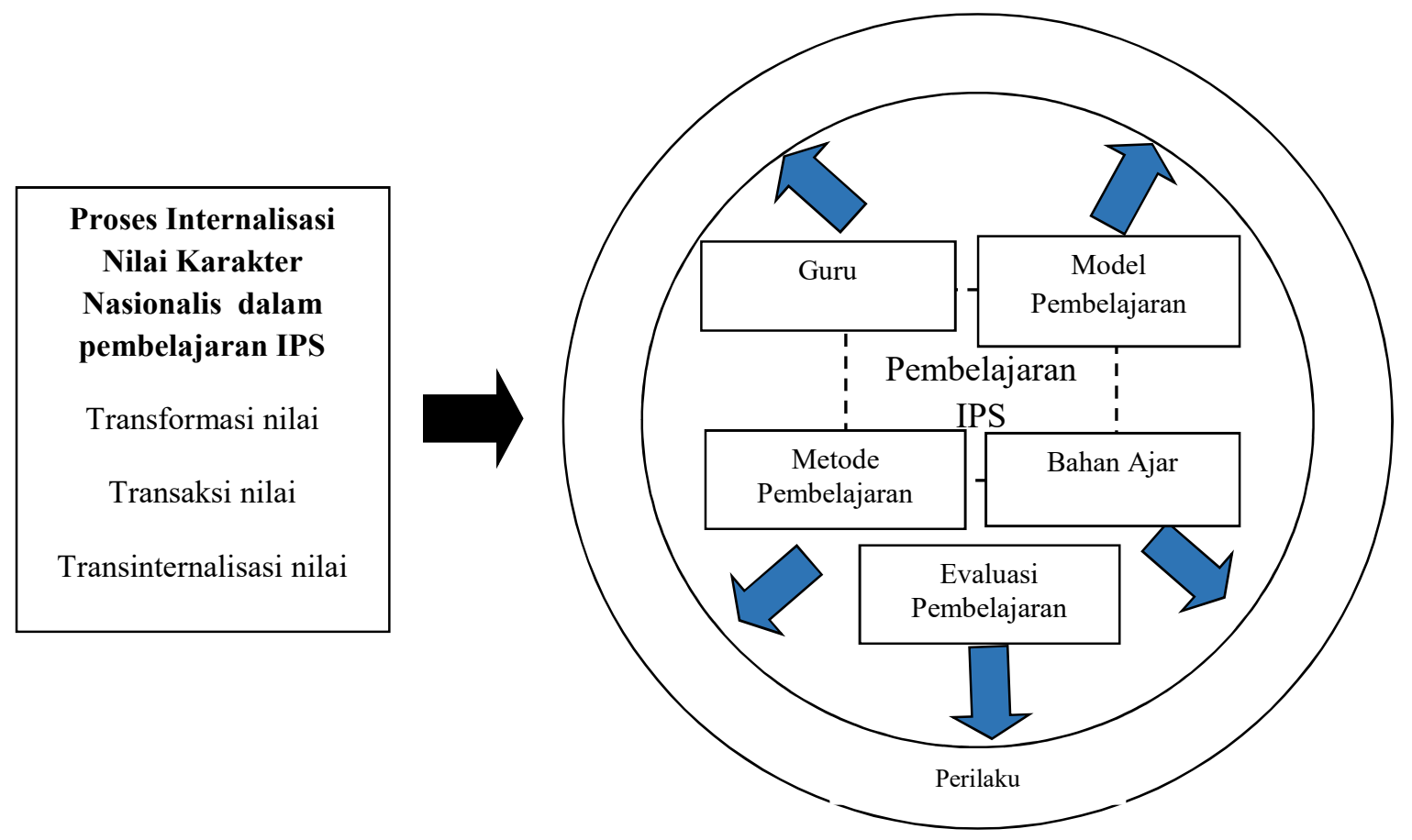

Gambar 1. Proses Internalisasi Nilai Karakter Nasionalis dalam Pembelajaran IPS (Sumber: Diolah Peneliti) 


\section{Hasil dan Pembahasan}

\section{Hasil Penelitian}

\section{Internalisasi Nilai Karakter Nasionalis dalam Pembelajaran IPS untuk Membangun Jati Diri Ke-Indonesia-an}

Internalisasi nilai karakter nasionalis dalam pembelajaran IPS diartikan sebagai proses penanaman nilai nasionalis kedalam jiwa seseorang sehingga nilai tersebut tercermin pada sikap dan prilaku yang ditampakkan dalam kehidupan sehari-hari (menyatu dengan pribadi). Proses internaslisasi tersebut melalui tiga tahap yaitu tahap transformasi nilai, tahap transaksi nilai, dan terakhir tahap transisternalisasi.

Proses internalisasi dimulai dari tahap tranformasi nilai diperoleh siswa ketika mereka mendengar secara langsung guru mereka menginformasikan kebaikan dari nilai karakter nasionalis dan kekurangannya apabila tidak memiliki nilai katakter tersebut. Berdasarkan hasil wawancara yang dilakukan kepada informan menunjukkan secara berbeda-beda mereka memaknai nilai karakter nasionalis yang disampaikan oleh guru mereka. Adapun sub nilai karakter nasionalis yang disampaikan oleh guru mereka yaitu disiplin, cinta tanah air, semangat kebangsaan, cinta damai, peduli lingkungan, menghargai prestasi, dan toleransi dengan menghormati keragaman budaya, suku,dan agama lain.

Tahapan selanjutnya setelah tahap transformasi nilai yaitu tahap transaksi nilai. Dalam tahap transaksi nilai ini terjadi komunikasi dua arah atau komunikasi antara peserta didik dengan pendidik yang bersifat interaksi timbal balik yaitu dalam pembelajaran IPS di kelas. Dalam tahap ini antara informan satu dengan yang lain memberikan makna yang berbeda-beda dari kegiatan pembelajaran IPS yang mereka ikuti selama ini. Nilai karakter nasionalis, seperti dari hasil wawancara yang telah dilakukan, dapat diketahui bahwa intenalisasi nilai karakter nasionalis dalam pembelajaran IPS melalui praktek kegiatan di kelas dalam memperoleh pengalaman belajar melalui model pembelajaran, metode pembelajaran, bahan ajar, dan evaluasi pembelajaran.
Model pembelajaran yang digunakan oleh guru IPS adalah model Problem Based Learning dan model Cooperative learning tipe Jigsaw. Berdasarkan hasil wawancara model pembelajaran yang digunakan oleh guru IPS dimaknai oleh siswa sebagai komunikasi dua arah yang mengandung nilainilai karakter bersahabat/ komunikatif melalui kerjasama, tanggung jawab, dan toleransi. Metode pembelajaran yang dipakai oleh guru IPS berdasarkan hasil wawancara oleh siswa yaitu metode ceramah, diskusi, dan Role Playing. Model dan metode pemebalajaran ini digunakan untuk menyampaikan informasi tentang nilai karakter nasionalis sub nilai disiplin, cinta tanah air, semangat kebangsaan, cinta damai, dan toleransi,

Bahan ajar yang digunakan dalam proses transaksi nilai yaitu bahan ajar berbasis $V C T$ atau biasa dikenal dengan Value Clarification Technique, bahan ajar ini memberi penekanan kepada siswa dalam usaha mengkaji perasaan dan perbuatan sendiri, untuk meningkatkan kesadaran mereka tentang nilai karakter nasionalis. Sedangkan evaluasi pembelajaran untuk menanamkan nilai menghargai prestasi dengan berlatih keras untuk berprestasi dalam matapelajaran IPS.Tahap terakhir dari proses internalisasi nilai karakter nasionalis yaitu tahap transinternalisasi. Tahap ini tidak hanya dilakukan dengan komunikasi verbal tetapi juga dengan sikap mental dan kepribadian. Dalam tahap ini masing-masing informan mempunyai kesamaan dalam proses transinternalisasi yaitu melalui komunikasi kepribadian yang melibatkan guru IPS sebagai teladan bagi siswa dalam proses internalisasi selanjutnya. Komunikasi kepribadian diwujudkan dalam melihat secarang langsung kepribadian guru dalam menerapkan nilai karakter nasionalis secara konsisten.

Dalam proses komunikasi kepribadian ini, yaitu dengan melihat secara langsung kepribadian guru IPS dan mendengar nasehat berupa kebaikan dan keburukan jika tidak/ kurang memiliki nilai karakter nasionalis tersebut sehingga munculah kesadaran dalam diri siswa tentang kebaikan nilai karakter tersebut. Selanjutnya dari kesadaran diri yang terbentuk pada siswa munculah upaya untuk 
menginternalisasi nilai karakter tersebut ke dalam diri mereka untuk menjadi bagian dalam diri mereka yang akhirnya diaktualisasikan dalam kehidupan sehari-hari mereka.

\section{Pentingnya Internalisasi Nilai Karakter Nasionalis dalam Pembelajaran IPS untuk Membangun Jati Diri Ke-Indonesia-an}

Pentingnya pendidikan karakter sebagai upaya memfasilitasi nilai karakter nasionalis dalam pembelajaran IPS dalam membangun jati diri ke-Indonesi-an. Meskipun sama tetapi setiap subjek penelitian memiliki sudut pandang yang berbeda.

ADN memaknai internalisasi nilai karakter nasionalis sebagai berikut.

"Menurut saya nasionalisme itu penting bagi penerus bangsa Indonesia terutama generasi muda demi kelangsungan hidup bangsa seperti kecintaan pada tanah air, semangat berbangsa dan bernegara dan rela berkorban. Misal dengan mencintai produk dalam negeri dan mengikuti upacara bendera"

ADN memaknai internalisasi nilai karakter nasionalis sebagai suatu keharusan bagi generasi muda demi kelangsungan hidup bangsa dan negar kedepannya. Nilai nasionalisme itu diwujudkan dalam mencintai produk dalam negeri dan mengikuti upacara bendera.

PSH memberikan pemaknaan internalisasi sebagai berikut.

"Menurut saya nasionalisme sangat penting untuk generasi muda seperti menghargai jasa para pahlawan menjunjung tinggi persatuan dan kesatuan bangsa. Tanpa nasionalisme maka sebuah bagsa akan hancur dan banyak pertikaian. Misalnya belajar bersungguhsungguh, mengembangkan bakat dan minat, mengikuti upacara, tidak tawuran, mentaati tata tertib sekolah, memperkenalkan budaya bangsa ke luar negeri, dan mencintai produk dalam negeri."

PSH memaknai internalisasi nilai karakter nasionalis sangattlah penting untk generasi muda. Nilai nasionalis tersebut diwujudkan dalam belajar bersungguh-sungguh, mengembangkan bakat dan minat, mengikuti upacara, tidak tawuran, mentaati tata tertib sekolah, memperkenalkan budaya bangsa ke luar negeri, dan mencintai produk dalam negeri.
IMS memaknai internalisasi sebagai berikut.

"Penting, karena nasionalisme mengandung rasa cinta tanah air, toleransi terhadap suku dan agama yang menjadi pemersatu bangsa. Misal dengan mencintai produk dalam negeri."

IMS memaknai internalisasi nilai karakter nasionalis sebagai hal yang penting yang diwujudkan dalam bentuk mencintai produk dalam negeri dan mementingkan kepentingan bangsa daripada kepentingan pribadi.

ADP memaknai internalisasi sebagai berikut.

"Bagi saya nasionalisme penting, sebab dengan di dalam nasionalisme terdapat rasa cinta tanah air, rela berkorban dan lain-lain. Misal dengan mengikuti upacara bendera, mencintai produk dalam negeri.

ADP memaknai internalisasi nilai karakter nasionalis merupakan hal yang penting pula dan diwujudkan dalam mengikuti upacara bendera, mencintai produk dalam negeri sebagai bagian bagian dari cinta tanah air dan rela berkorban.

TWI memaknai internalisasi sebagai berikut

"Menurut saya nasionalisme itu penting, karena sikap nasionalisme itu memuat sikap cinta tanah air, toleransi, dan sikap kebangsaan yang lain. Misal dengan kita menjaga warisan budaya dan mencintai produk dalam negeri."

TWI memaknai internalisasi nilai karakter nasionalis merupakan hal yang penting karena memuat sikap cinta tanah air, toleransi, dan sikap kebangsaan yang lain. Nilai karakter nasionalis tersebut diwujudkan dengan kita menjaga warisan budaya dan mencintai produk dalam negeri.

TAP memaknai internalisasi sebagai berikut.

"Nasionalisme adalah sikap dasar warga negara, jadi sangat penting seperti bela negara, cinta tanah air. Sehingga semua warga negara harus menjunjung tinggi sekap nasionalisme. Misal dengan siap membela bangsa dan negara dari ancaman negara lain." 
TAP memaknai internalisasi nilai karakter nasionalis sebagai hal yang penting sebagai sikap dasar warga negara seperti bela negara dan cinta tanah air. Wujud nilai karakter nasionalis yaitu dengan siap membela bangsa dan negara dari ancaman negara lain.

EDM memaknai internalisasi sebagai berikut.

"Penting, karena nasionalisme mengandung rasa cinta tanah air, toleransi, tanpa rasa tersebut bangsa Indonesia akan terpecah belah dan bangsa Indonesia tidak akan menjadi negara maju. Misal dengan mencintai produk dalam negeri, menjaga warisan Indonesia, dan mementingkan kepentingan bangsa."

EDM memaknai internalisasi nilai karakter nasionalis sebagai hal yang penting karena nasionalisme mengandung rasa cinta tanah air dan toleransi. Nilai karakter nasionalis diwujudkan dengan mencintai produk dalam negeri, menjaga warisan Indonesia, dan mementingkan kepentingan bangsa.

STG memaknai internalisasi sebagai berikut.

"Nasionalisme itu penting karena adanya jiwa nasionalisme itu tercipta rasa cinta tanah air dan toleransi. Nasionalisme diwujudkan dengan mencintai produk dalam negeri dan menjaga warisan budaya."

STG memaknai internalisasi nilai karakter nasionalis sebagai hal yang penting untuk tercipta rasa cinta tanah air dan toleransi. Nasionalisme diwujudkan dengan mencintai produk dalam negeri dan menjaga warisan budaya.

Berdasarkan pendapat delapan subyek penelitian yang sudah dikemukakan oleh ADN, PSH, IMS, ADP, TWI, TAP, EDM, dan STG, berpendapat bahwa internalisasi nilai karakter nasionalis sangat penting untuk generasi muda demi kelangsungan hidup bangsa. Wujud nilai karakter nasionalis dari delapan informan memiliki jawaban yang berbeda-beda seperti mencintai produk dalam negeri, mengikuti upacara bendera, belajar bersungguh-sungguh, mengembangkan bakat dan minat, tidak tawuran, mentaati tata tertib sekolah, memperkenalkan budaya bangsa ke luar negeri, menjaga warisan budaya, dan terakhir dengan siap membela bangsa dan negara dari ancaman negara lain.

\section{Sintesis}

Berdasarkan temuan hasil penelitian, dapat disintesiskan bagaimana hubungan antara: 1) proses internalisasi nilai karakter nasionalis; 2) makna internalisasi nilai karakter nasionalis; dan 3) perilaku berkarakter nasionalis yang diaktualisasikan dalam kehidupan sehari-hari untuk membangun jati diri ke-Indonesia-an.

Pentingnya nilai karakter nasionalis dalam pembelajaran IPS untuk di internalisasikan pada diri siswa membuat siswa berperilaku berkarakter sesuai dengan nilai-nilai yang dia yakini. Namun perilaku berkarakter tersebut tidak bisa muncul dengan sendirinya tanpa adanya proses internalisasi dan proses internalisasi tidak bisa berjalan tanpa adanya penyampaian informasi melalui pembelajaran IPS.

Proses internalisasi nilai karakter nasionalis dalam pembelajaran IPS melalui keteladanan guru dan kegiatan praktek langsung pengalaman belajar melalui model pembelajaran, metode pembelajaran, bahan ajar, dan evaluasi pembelajaran. Nilai-nilai karakter diinternalisasikan dalam tiga tahap yang mewakili proses atau tahap terjadinya internalisasi yaitu tahap transformasi nilai, tahap transaksi nilai, dan terakhir tahap transisternalisasi. Perilaku berkarakter yang diaktualisasikan oleh siswa dalam kehidupan sehari-hari mereka sesuai dengan prinsip jati diri ke-Indonesia-an yang meliputi: 1) kesatuan (unity); 2) kebebasan (liberty); 3) kesamaan (equality); (4) kepribadian (personality); dan 5) prestasi yang dicapai (achievment) yaitu disiplin, cinta tanah air, semangat kebangsaan, cinta damai, peduli lingkungan, menghargai prestasi, dan toleransi dengan menghormati keragaman budaya, suku,dan agama lain.

Berdasarkan hasil penelitian yang diperoleh dua proposisi yaitu: 1) internalisasi nilai karakter nasionalis dalam pembelajaran IPS mempunyai peran dalam membentuk perilaku berkarakter sesuai dengan jati diri keIndonesiaan; dan 2) internalisasi nilai karakter nasionalis dalam membentuk perilaku berkarakter yang sesuai dengan jati diri keIndonesia-an melalui pembelajaran IPS dengan mediator guru, dan melalui praktik pengalaman melalui model pembelajaran, metode pembelajaran, evaluasi pembelajaran dan bahan ajar. 


\section{Pembahasan}

Nilai karakter nasionalis diintegrasikan dalam proses pembelajaran IPS dilakukan dengan cara mengenalkan, memfasilitasi, dan menginternalisasikan nilai karakter nasionalis dalam perilaku sehari-hari. Nilai karakter tersebut diinternalisasikan pada peserta didik melalui proses pembelajaran IPS karena dianggap penting seiring gejala memudarnya jati diri ke-Indonesia-an di kalangan pelajar saat ini.

Internalisasi nilai karakter nasionalis diartikan sebagai proses penanaman nilai nasionalis kedalam jiwa seseorang sehingga nilai tersebut tercermin pada sikap dan perilaku yang ditampakkan dalam kehidupan sehari-hari (menyatu dengan pribadi). Proses internalisasi nilai nasionalis yang dikaitkan dengan pembinaan peserta didik atau anak asuh ada tiga tahap yang mewakili proses atau tahap terjadinya internalisasi yaitu: a) Tahap transformasi nilai, tahap ini merupakan suatu proses yang dilakukan oleh pendidik dalam menginformasikan nilai nasionalis. Komunikasi yang terjadi dalam tahap ini adalah komunikasi verbal antara pendidik dan peserta didik; b) Tahap transaksi nilai, adalah suatu tahap pendidikan nilai nasionalis dengan jalan melakukan komunikasi dua arah atau komunikasi antar peserta didik dengan pendidik yang bersifat interaksi timbal balik dalam hal ini melalui pembelajaran IPS; dan c) Tahap transisternalisasi, tahap ini jauh lebih mendalam dari tahap transaksi yaitu dengan sikap mental dan kepribadian. Jadi pada tahap ini, komunikasi kepribadian berperan secara aktif.

Internalisasi dalam prosesnya hanya akan berlangsung dengan berlangsungnya identifikasi. Berger dan Luckman (1990, p.185) mengemukakan bahwa dalm proses internalisasi terjadi proses pengidentifikasian dalam diri orang tersebut. Anak dalam hal ini peserta didik mengidentifikasikan dirinya dengan orang-orang yang mempengaruhinya dengan berbagai cara emosional. Wujud identifikasi pada diri peserta didik yaitu dengan membentuk suatu kecenderungan untuk menyamakan (menjadi sama) diri dengan orang lain. Karena adanya kecenderungan tersebut individu melakukakan suatu usaha yang disebut tindakan sosial untuk menjadikan dirinya sama dengan orang yang dimaksudnya.

Dalam proses identifikasi pada diri siswa, faktor keteladanan guru dalam hal ini guru IPS yang mempunyai peran yang penting untuk menjadi sama dengan gurunya. Hal ini sebagaimana yang dinyatakan dalam teori perkembangan moral Kohlberg (Adisusilo, 2012, p.24) bahwa tingkat perkembangan moral siswa SMP berada pada tahap konvensional. Pada tahap ini secara aktif siswa mengidentifikasikan diri dengan orangorang dan kelompok yang terlibat di dalamnya.

Dalam proses internalisasi nilai karakter nasionalis dalam pembelajaran IPS untuk membangun jati diri ke-Indonesia-an, guru mempunyai peran dalam proses internalisasi nilai-nilai karakter pada siswa yang pada akhirnya membentuk perilaku siswa yang berkarakter. Guru dapat menggunakan berbagai macam strategi dalam menanamkan nilai-nilai karakter pada diri siswa misal dengan metode ceramah, yaitu guru dalam menginformasikan kebaikan serta keburukannya apabila tidak/ kurang memiliki nilai karakter tersebut.

Selanjutnya selain dengan ceramah, guru sebagai simbol keteladanan bagi siswa dalam proses intenalisasi nilai-nilai karakter. Komunikasi kepribadian antara guru dan siswa menjadi begitu penting ketika siswa melihat secara langsung kepribadian guru dalam menerapkan nilai-nilai karakter tersebut. Marzuki (2012) integrasi pendidikan karakter dalam pembelajaran dimulai dari perencanaan, pelaksanaan, hingga evaluasinya selanjutnya dalam pelaksanaannya pendidikan karakter di sekolah perlu didukung oleh keteladanan guru dan budaya yang berkarakter. Selanjtnya Marzuki dan Danang Prasetyo (2016) pendidikan karakter melalui keteladanan guru dapat berupa tutur kata, ciri kepribadian, sikap, dan penampilan.

Dalam pembelajaran IPS, proses internalisasi nilai karakter nasionalis dibutuhkan pula praktik pengalaman langsung dalam menerapkan nilai karakter tersebut sehingga membentuk perilaku berkarakter pada siswa. Praktik pengalaman langsung tersebut melalui aktivitas siswa dalam menggunakan model pembelajaran, metode pembelajaran, bahan ajar, dan evaluasi pembelajaran yang di desain oleh guru. Ramdani dan Zamroni (2014) hasil 
penelitiannya menunjukkan bahwa guru harus dapat mendesain model pembelajaran yang relevan agar para siswa dalam pembelajaran IPS tidak hanya mendapatkan materi saja tetapi juga mendapatkan nilai/makna sekaligus dari materi yang dipelajari.

Praktek pengalaman langsung dalam pembelajaran IPS melalui kegiatan pembiasaan dan pengkondisian dalam kelas untuk menumbuhkan kesadaran diri pada siswa yang selanjutnya nilai karakter nasionalis diinternalisasi oleh siswa dan pada muaranya diaktualisasikan siswa pada kehidupan sehari-hari sebagai wujud perilaku berkarakter. Innayah (2012) dibutuhkan strategi dalam pendidikan karakter melalui pembiasaan dan penanaman paradigma bagi peserta didik tentang pentingnya pengembangan karakter diri karena keberhasilan pengembangan karakter juga bergantung kesadaran diri anak.

Berdasarkan hasil diskusi di atas diketahui bahwa dalam proses internalisasi nilai karakter nasionalis pada masing-masing individu tidaklah sama dikarenakan terdapat perbedaan sikap, persepsi, dan partisipasi masing-masing individu dalam keterlibatan memperoleh pengalaman secara langsung. Nilai karakter nasionalis dalam pembelajaran IPS yang berhasil diaktualisasikan oleh peserta didik yaitu disiplin, cinta tanah air, semangat kebangsaan, cinta damai, peduli lingkungan, menghargai prestasi, dan toleransi dengan menghormati keragaman budaya, suku,dan agama lain.

Sehingga dari aktualisasi nilai karakter nasionalis yang diaktualisasikan oleh peserta didik diatas diketahui bahwa dalam membangun jati diri ke-Indonesia-an dapat dilakukan melalui penguatan pendidikan karakter. Hal yang sama ditunjukkan oleh hasil penelitian Sa'adah (2015) bahwa diperlukan sebuah identitas tentang jati diri bangsa yang dapat ditempuh melalui pendidikan karakter sehingga dapat menciptakan sumber daya manusia yang kreatif.

Nilai karakter nasionalis tersebut dalam pembelajaran IPS diperoleh melalui.

1. Keteladanan guru berupa tutur kata, kepribadian, sikap, dan penampilan dalam menerapkan nilai karakter nasionalis dalam pembelajaran IPS setiap harinya.

2. Praktek pengalaman langsung dalam aktivitas siswa. Aktivitas-aktivitas siswa tersebut meliputi.

a. Model pembelajaran melalui Problem Based Instruction dan Cooperative Learning tipe Jigsaw.

b. Metode pembelajaran kegiatan ceramah, diskusi kelompok dan Role Playing.

c. Bahan ajar melalui buku IPS berbasis VCT (Value Clarification Technique).

d. Evaluasi pembelajaran melalui kegiatan Ulangan harian matapelajaran IPS.

Internalisasi nilai karakter nasionalis dalam pembelajaran IPS dengan mediator guru, dan melalui praktik pengalaman melalui model pembelajaran, metode pembelajaran, evaluasi pembelajaran dan bahan ajar sangat penting untuk generasi muda demi kelangsungan hidup bangsa. Ketika nilai karakter nasionalis sudah terinternalisasi dalam diri peserta didik diharapkan dapat membangun jati diri keIndonesia-an sesuai dengan lima prinsip nasionalisme seperti mencintai produk dalam negeri, mengikuti upacara bendera, belajar bersungguh-sungguh, mengembangkan bakat dan minat, tidak tawuran, mentaati tata tertib sekolah, memperkenalkan budaya bangsa ke luar negeri, menjaga warisan budaya, dan terakhir dengan siap membela bangsa dan negara dari ancaman negara lain. 



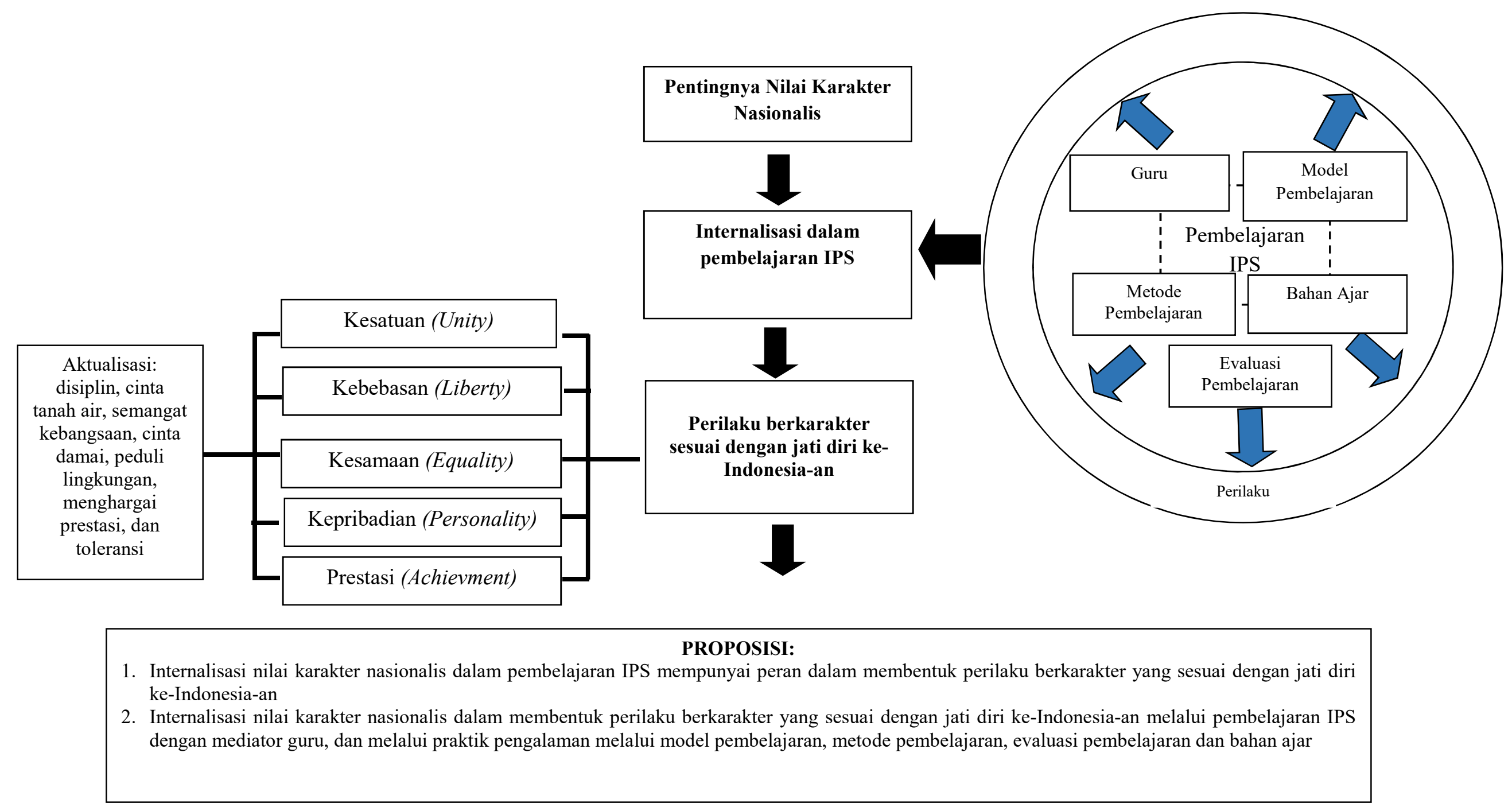

Gambar 2 Sintesis Hasil Penelitian

(Sumber: Temuan Penelitian, diolah peneliti) 



\section{Simpulan dan saran}

\section{Simpulan}

Internalisasi nilai karakter nasionalis pada dasarnya adalah proses penanaman nilai karakter nasionalis ke dalam diri seseorang sehingga nilai-nilai tersebut menjadi bagian dalam dirinya, menjiwai pola pikir, pola sikap, dan perilakunya serta membangun kesadaran diri untuk mengaplikasikan nilai tersebut. Internalisasi nilai karakter nasionalis dalam pembelajaran IPS melalui tiga tahap yaitu tahap transformasi nilai, tahap transaksi nilai, dan terakhir tahap transisternalisasi. Transformasi nilai ditunjukkan dengan siswa menerima langsung nilai karakter nasionalis yang diinformasikan oleh guru IPS mereka melalui metode ceramah ketika menginformasikan kebaikan nilai dan kejelekkan apabila tidak atau kurang mempunyai nilai karakter nasionalis tersebut.

Selanjutnya tahap transaksi nilai yaitu komunikasi dua arah antara guru dan peserta didik dalam pembelajaran IPS melalui kegiatan praktik langsung untuk memperoleh pengalaman belajar. Praktik pengalaman langsung dalam aktivitas siswa. Aktivitasaktivitas siswa tersebut meliputi: 1) Model pembelajaran melalui Problem Based Learning dan Cooperative Learning tipe Jigsaw; 2) Metode pembelajaran kegiatan ceramah, diskusi kelompok, dan Role Playing; 3) Bahan ajar melalui buku IPS berbasis VCT (Value Clarification Technique); dan 4) Evaluasi pembelajaran melalui kegiatan Ulangan harian pada mata pelajaran IPS.

Tahap terakhir yaitu tahap transinternalisasi nilai melalui komunikasi kepribadian. Pada tahap ini siswa melihat secara langsung kepribadian guru dalam menerapkan nilai karakter nasionalis. Ketika peserta didik melihat secara langsung kepribadian guru dan mendengar nasehat tentang nilai karakter tersebut, selanjutnya muncul kesadaran dalam diri siswa untuk menginternalisasi nilai karakter nasionalis ke dalam diri mereka untuk menjadi bagian dalam diri mereka yang akhirnya diaktualisasikan dalam kehidupan sehari-hari mereka.

Perilaku berkarakter yang diaktualisasikan oleh siswa dalam kehidupan sehari-hari mereka sesuai dengan prinsip jati diri ke-
Indonesia-an yang meliputi: 1) kesatuan (unity); 2) kebebasan (liberty); 3) kesamaan (equality); (4) kepribadian (personality); dan 5) prestasi yang dicapai (achievment) yaitu disiplin, cinta tanah air, semangat kebangsaan, cinta damai, peduli lingkungan, menghargai prestasi, dan toleransi dengan menghormati keragaman budaya, suku,dan agama lain.Internalisasi nilai karakter nasionalis sangat penting untuk generasi muda demi kelangsungan hidup bangsa. Wujud nilai karakter nasionalis seperti mencintai produk dalam negeri, mengikuti upacara bendera, belajar bersungguh-sungguh, mengembangkan bakat dan minat, tidak tawuran, mentaati tata tertib sekolah, memperkenalkan budaya bangsa ke luar negeri, menjaga warisan budaya, dan terakhir dengan siap membela bangsa dan negara dari ancaman negara lain.

\section{Saran}

Berdasarkan simpulan hasil penelitian, maka saran penelitian ini sebagai berikut: 1) Nilai karakter nasionalis yang berhasil diinternalisasikan oleh siswa sebaiknya tetap dipertahankan keberadaannya untuk membangun jati diri ke-Indonesia-an; 2) Perlu dikembangkan model-model pembelajaran yang aktif, inovatif, kreatif, dan menyenangkan atau biasa disebut PAIKEM dengan berbagai program pembiasaan untuk internalisasi nilai karakter nasionalis pada peserta didik; dan 4) Menciptaan lingkungan pendidikan yang kondusif-edukatif, misalnya dipajang berbagai slogan-slogan yang mampu memberikan motivasi kepada seluruh warga sekolah dalam membangun jati diri keIndonesia-an seperti apresiasi budaya bangsa sendiri, menjaga kekayaan budaya bangsa, rela berkorban, unggul, dan berprestasi, cinta tanah air, menjaga lingkungan,taat hukum, disiplin, menghormati keragaman budaya, suku,dan agama.

\section{DAFTAR PUSTAKA}

Adisusilo, Sutarjo R. (2013). Pembelajaran Nilai Karakter-Konstruktivisme dan VCT Sebagai Inovasi Pendekatan Pembelajaran Afektif. Jakarta: Rajawali Pers.

Anonym. (2014). Jalan Perubahan Untuk Indonesia Berdaulat, Mandiri, dan 
Berkepribadian: Visi, Misi, dan Program Aksi. http://kpu.go.id/koleksigambar/VISI_ MISI_Jokowi-JK.pdf. Diunduh 9 Maret 2017.

Berger, Peter. L dan Luckmann, Thomas. (1990). Tafsir Sosial atas Kenyataan. Risalah tentang Sosiologi Pengetahuan. Jakarta : LP3ES

Creswell, John W. (2013). Penelitian Kualitatif dan Desain Riset: Memilih di antara Lima Pendekatan. Jakarta: Pustaka Pelajar.

Innayah. (2012). "Dongeng Anak Nusantara radio Edukasi (RE) sebagai Media untuk Penanaman Karakter Bangsa". Jurnal Teknodik: Terakreditasi LIPI No. 464/AU1/P2MI-LIPI/08/ 2012.

Kartodirdjo, Sartono. (1994). Pembangunan Bangsa, Nasionalisme, Kesadaran Sejarah, dan Kebudayaan Nasional. Jakarta: Gramedia Pustaka Utama.

Kartodirdjo, Sartono. (1999). Multidimensi Pembangunan Bangsa Etos Nasionalisme Negara Kesatuan. Yogyakarta: Kanisius.

Kemdikbud. (2016). Konsep dan Pedoman Penguatan Pendidikan Karakter Tingkat Sekolah Dasar dan Sekolah Menengah Pertama.

Kemdikbud. (2017). Modul Penguatan Pendidikan Karakter bagi Guru.

Lickona, Thomas. (2013). Educating for Character: Mendidik untk Membentuk Karakter, terj. Juma Wadu Wamaungu dan Editor Uyu Wahyuddin dan Suryani. Jakarta: Bumi Aksara.

Marzuki. (2012). "Pengintegrasian Pendidikan Karakter Dalam Pembelajaran di
Sekolah.” Jurnal Pendidikan Karakter Edisi Februari 2012 TH. II No.1. (pp. 33-44)

Marzuki. (2016). "Pembinaan Karakter Melalui Keteladanan Guru Pendidikan Kewarganegaraan di Sekolah Islam Al Azhar Yogjakarta." .Jurnal Pendidikan Karakter, Tahun VI, Nomor 2, Oktober 2016. (pp. 215231)

Muhaimin. (2001). Paradigma Pendidikan Islam: Upaya Mengefektifkan Pendidikan Agama Islam di sekolah. Bandung: PT. Remaja Rosdakarya.

Permendiknas No.26. 2007. Standar isi.

Ramdani, Zuhud dan Zamroni. 2014. "Integrasi Pendidikan Karakter dalam Pembelajaran IPS di MTsN Model Selong Lombok Timur". Jurnal ilmuilmu sosial Mei 2014 , Vol. 11, No. 1. (pp.104-117).

Sa'adah, Zumrottus. "Jati Diri Bangsa dan Sumber Daya Konstruktif Sebagai asset Ekonomi Kreatif di Indonesia." Jurnal Economia Volume 11 Nomor 2 Oktober 2015. (pp. 150-160.)

\section{Profil Penulis.}

Eko Prasetyo Utomo lahir di Bojonegoro 22 Desember 1985. Menempuh pendidikan S1 Pendidikan Ekonomi Fakultas Ekonomi Universitas Negeri Surabaya (Unesa) lulus tahun 2008. Pada tahun 2010 melanjutkan S2 Pendidikan Ekonomi di PPs Universitas Sebelas Maret Surakarta (UNS) lulus pada tahun 2012. Pada tahun 2014 mendapatkan Beasiswa dari P2TK Dikdas Kemdikbud S2 Pendidikan IPS di PPs Universitas Negeri Surabaya dan lulus tahun 2016. 